\title{
Pituitary Gland Neoplasm
}

National Cancer Institute

\section{Source}

National Cancer Institute. Pituitary Gland Neoplasm. NCI Thesaurus. Code C3330.

A benign or malignant neoplasm affecting the pituitary gland. The vast majority are adenomas arising from the anterior lobe of the pituitary gland. 